\title{
MONITORING KARBON MONOKSIDA (CO) DAN PARAMETER METEOROLOGIS DI TERMINAL TAWANG ALUN KABUPATEN JEMBER
}

\author{
${ }^{1)}$ Norry Levi Purnama , 1)Yushardi , 1) Agus Abdul Gani \\ Program Studi Pendidikan Fisika FKIP Universitas Jember \\ Email: norrylevi@gmail.com
}

\begin{abstract}
Tawang Alun Terminal Jember Regency is one of the dense areas of vehicles have potential to experience carbon monoxide gas pollution and very low rainfall compared to the surrounding neighborhoods. This research has shown the condition of air and carbon monoxide concentration in terminal area of Tawang Alun. Monitoring used a set of sensor-based tools with an Arduino microcontroller. The results of monitoring of carbon monoxide and meteorological parameters, obtained the highest concentration of carbon monoxide occured during the day but gradually decreased in the afternoon until late in the night when the temperature was getting down and the air humidity increases. In contrast to the amount of wind speed that showed the linear distribution pattern as time changed. The average result of carbon monoxide measurements on holidays is 71,000-158,000 $\mu \mathrm{g} / \mathrm{Nm}^{3}$ on weekdays of 62,000-69,000 $\mu \mathrm{g} / \mathrm{Nm}^{3}$. This value showed that has exceeded the ambient air quality standard limit for carbon monoxide gas is 30,000 $\mu \mathrm{g} / \mathrm{Nm}^{3}$. The amount of carbon monoxide content is influenced by the volume of vehicles with a regression rate of $82.3 \%$.
\end{abstract}

Keywords: Carbon Monoxide, meteorological parameters, the ambient air quality standard

\section{PENDAHULUAN}

Polusi udara menjadi topik penting dalam penelitian atmosfer bumi. Hal ini dikarenakan masalah yang ditimbulkan seperti pemanasan global atau global warming telah menyebabkan perubahan iklim yang tidak menentu. Selain itu kebutuhan akan udara bersih merupakan kebutuhan utama bagi manusia yang tinggal di bumi. Namun menurut hasil penelitian Sarwono (2010) pemaknaan fenomena pemanasan global dalam konteks kepedulian terhadap perubahan iklim masih sebatas gaya hidup. Menurut Soegeng (1994:15), untuk memaknai perubahan iklim perlu memahami dua daerah, yaitu atmosfer bawah dan atmosfer atas. Atmosfer bawah mulai dari permukaan bumi sampai ketinggian sekitar $50 \mathrm{~km}$. Daerah ini ditangani oleh bidang meteorologi. Sedangkan atmosfer atas mulai dari ketinggian $50 \mathrm{~km}$ dan ditangani oleh bidang aeronomi. Pada atmosfer bawah, pembagian berdasarkan pengaruh suhu terdapat pada daerah Troposfir. Pembagian berdasarkan pengaruh keadaan gas terdapat pada daerah Homosfir. Berdasarkan pengaruh sifat-sifat gas termasuk pada daerah Barosfir, serta berdasarkan macam-macam partikel pada daerah homosfir yang umumnya berupa moleku-molekul gas. Hal ini dikarenakan pada daerah heterosfir molekul-molekul mulai terdiosiasi. Sedangkan berdasarkan pengaruh medan magnet bumi terlampau jauh didaerah ionosfir ke atas atau yang disebut sebagai daerah ionopause dan maknetosfir yang memiliki ketinggian 10 kali jari-jari bumi dimana terdapat angin matahari. Jadi, dalam penelitian atmosfer bumi pada ketinggian kurang dari $50 \mathrm{~km}$ dapat dikaji berdasarkan parameter meteorologi secara fisik yang kemudian 
didapatkan data berupa suhu dan kelembaban pada daerah troposfir serta kecepatan angin pada daerah homosfir.

Menurut data monografi tahun 2013, Kabupaten Jember merupakan kabupaten yang termasuk dalam klasifikasi kota sedang memiliki potensi ekonomi yang besar dan dapat dikembangkan. Hal ini dikarenakan sampai dengan tahun 1990 jumlah penduduk mencapai 244.341 jiwa, dimana berdasarkan kriteria BPS mengenai kelas kota, kota sedang merupakan kota dengan jumlah penduduk antara 100.000 sampai 500.000 jiwa. Jika melihat perkembangan distribusinya, hingga tahun 2013 terdapat pertambahan jumlah penduduk yang cukup signifikan, yakni meningkat menjadi 2.334.440 jiwa. Menurut hasil kajian Prasetyo (2016) pertumbuhan ekonomi merupakan salah satu penyebab kemacetan lalu lintas perkotaan. Begitupun dengan jumlah sarana angkutan umum Bus AKAP dan AKDP yang telah mengalami peningkatan sampai tahun 2013. Berdasarkan data Dinas Perhubungan Kabupaten Jember

mengenai jumlah kendaraan yang beroperasi sampai Tahun 2016 mencapai 451 unit untuk kendaraan angkutan umum, yakni meliputi angkutan kota, angkutan pedesaan, dan Taksi. Sedangkan menurut peta prasarana transportasi jalan Ditjen Perhubungan Darat tahun 2013 data luas terminal angkutan penumpang, yakni di Terminal Tawang Alun Kabupaten Jember tipe A mencangkup $30.000 \mathrm{~m}^{2}$. Menurut Ismiyati et al. (2014) Perkembangan

jumlah kendaraan yang cepat (eksponensial) berbanding lurus dengan tingkat penggunaan transportasi serta aktivitas pedagang kios maupun kaki lima yang banyak berpusat di titik-titik kemacetan sekitar kawasan terminal.

Seiring dengan berkembangnya transportasi darat, timbul masalah lingkungan, yakni pencemaran udara. Menurut Haris et al. (2012) pencemaran udara adalah bertambahnya bahan pencemar ke dalam lingkungan udara normal yang memberikan efek pada manusia dan lingkungan. Menurut hasil penelitian Megalina (2015) pencemaran udara di Terminal Amplas yang banyak dijumpai adalah pengotoran udara akibat gas buang dari kendaraan bermotor dan juga asap rokok para supir serta penumpang bus, angkot, mobil, maupun kendaraaan lainnya. Menurut hasil penelitian Aprilina et al. (2016) adanya karbon monoksida (CO) yang tidak berwarna, tidak berbau, dan bersifat racun diduga karena adanya pengaruh dari faktor lain terutama yang disebabkan oleh aktivitas manusia (faktor anthropogenik). Berdasarkan hasil analisis dan pembahasan pada penelitian Sengkey et al. (2011) mengenai tingkat konsentrasi gas karbon monoksida (CO) akibat lalu lintas di ruas jalan Sam Ratulangi Manado, didapatkan konsentrasi polutan $\mathrm{CO}$ yang ada di udara, $80,22 \%$ - 92,00\% berasal dari kendaraan bermotor. Sedangkan menurut penelitian Suryaningsih et al. (2017) hasil pengujian di beberapa lokasi, didapat data konsentrasi gas CO sebesar 1,89 ppm pada daerah yang tidak berpotensi adanya polusi dan 103,35 ppm pada daerah yang berpotensi adanya polusi. Salah satu kegiatan dalam pengendalian pencemaran udara adalah pemantauan kualitas udara ambien. Hal ini digunakan untuk mengetahui penggolongan udara bersih dan udara tercemar digunakan klasifikasi menurut rentang cemaran bahan partikel dan gas yang boleh terkandung dalam udara. Menurut hasil observasi peneliti di dinas Lingkungan Hidup Kabupaten Jember ditemukan kendala, yakni belum adanya monitoring secara berkala akibat kurangnya persediaan alat yang cukup memadai guna melakukan pemantauan terhadap kualitas udara di Kabupaten Jember. Untuk itu diperlukan monitoring yang dapat memantau kondisi udara secara berkala di titik- titik yang rawan tercemar. Kini berkembang piranti elektronik canggih berbasis sensor yang tersebar luas di pasaran dengan berbagai jenis spesifikasi. 
Berdasarkan uraian mengenai masalah lingkungan tersebut, maka tujuan penelitian yang dikemukakan dalam penelitian ini adalah (1) mengkaji pola konsentrasi karbon monoksida (CO) dan parameter meteorologi (kelembaban, suhu, dan kecepatan angin) berdasarkan perubahan waktu di Terminal Tawang Alun Kabupaten Jember; (2) mengkaji hubungan volume kendaraan terhadap konsentrasi karbon monoksida (CO) di Terminal Tawang Alun Kabupaten Jember; (3) mengkaji ada atau tidaknya perbendaan konsentrasi karbon monoksida (CO) yang signifikan di Terminal Tawang Alun Kabupaten Jember dengan hasil kontrol alamiah di daerah persawahan.

\section{METODE PENELITIAN}

Jenis penelitian ini adalah penelitian deskriptif yang dilaksanakan di terminal Tawang Alun Kabupaten Jember dan di area persawahan sebagai hasil kontrol alamiah di Kecamatan Ajung Kabupaten Jember. Sampel penelitian ditentukan di ketinggian 8 meter diatas permukaan tanah. Data yang digunakan adalah data hasil monitoring secara berkala dan serentak pada waktu pagi (pukul 07.00 WIB), waktu siang (pukul $12.00 \mathrm{WIB}$ ), waktu sore (pukul 17.00 WIB). Metode pengumpulan data dalam penelitian ini antara lain menggunakan: observasi, test, dokumentasi dan wawancara. Teknik

analisis data untuk mengetahui perbedaan konsentrasi karbon monoksida di terminal Tawang Alun dengan di daerah persawahan, maka di lakukan uji independent sample t-test dengan persamaan:

$$
t_{t \text { test }}=\frac{M_{x}-M_{y}}{\sqrt{\left(\frac{\sum x^{2}+\sum y^{2}}{N_{x}+N_{y-2}}\right)\left(\frac{1}{N_{x}}+\frac{1}{N_{y}}\right)}}
$$

(Arikunto, 2010:354)
Keterangan:

$M x$ = nilai rata-rata konsentrasi karbon monoksida di terminal Tawang Alun;

$M y=$ nilai rata-rata konsentrasi karbon monoksida di sawah;

$\Sigma \mathrm{x}^{2}=$ jumlah kuadrat deviasi di terminal

Tawang Alun;

$\Sigma \mathrm{y}^{2}=$ jumlah kuadrat deviasi di sawah;

$N x=$ banyaknya sampel pada di terminal

Tawang Alun;

$N y$ = banyaknya sampel pada di sawah Untuk mengkaji hubungan antara

jumlah kendaraan dengan tingkat konsentrasi karbon monoksida, maka dilakukan uji regresi menggunakan aplikasi SPSS dengan hipotesis sebagai berikut:

a. $\mathrm{H}_{0}: x=y$ (terdapat hubungan antara jumlah kendaraan dengan tingkat konsentrasi karbon monoksida)

b. $\mathrm{H}_{\mathrm{a}}: x \neq y$ (tidak terdapat hubungan antara jumlah kendaraan dengan tingkat konsentrasi karbon monoksida).

Penentuan nilai uji statistik siswa menggunakan uji independent samples $t$ test pada program SPSS 22.

\section{HASIL DAN PEMBAHASAN}

Data Berikut tabel rata-rata hasil monitoring selama 1 jam:

Tabel 1. Hasil Pengukuran Konsentrasi Gas Karbon Monoksida (CO) dan Parameter Meteorologis Terhadap Perubahan Waktu di Terminal Tawang Alun

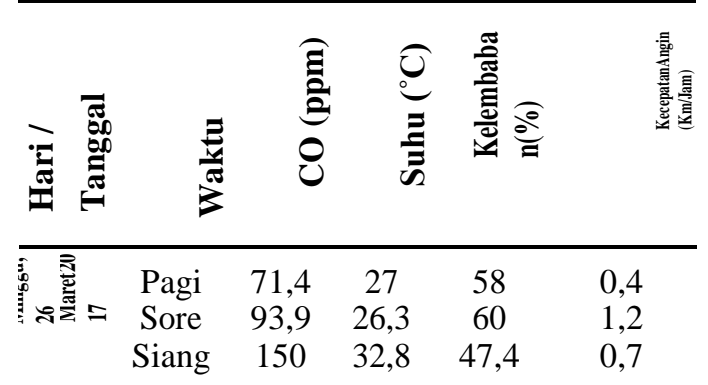

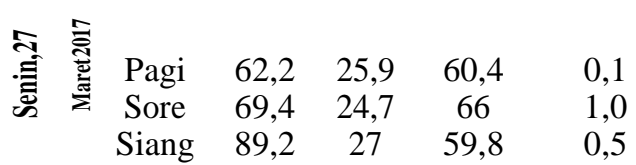


Berdasarkan Tabel 1 didapatkan pola distribusi karbon monoksida dan parameter meteorologis berdasarkan perubahan waktu pada saat hari libur sebagai berikut:

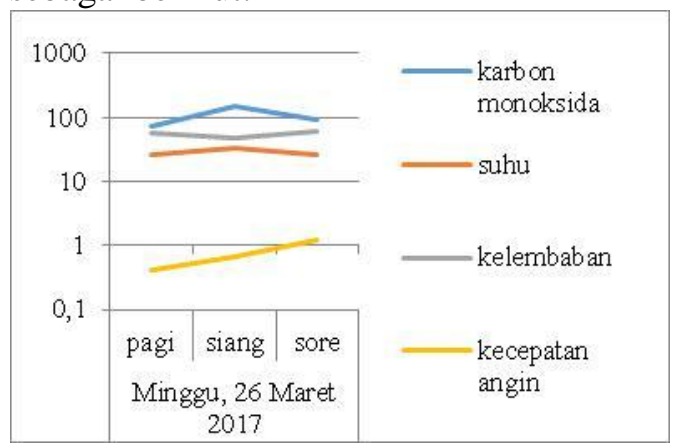

Gambar 1. Pola Distribusi Karbon Monoksida dan Parameter Meteorologis Berdasarkan Perubahan Waktu Pada Saat Hari Libur

Sedangkan pola distribusi karbon monoksida dan parameter meteorologis berdasarkan perubahan waktu pada saat hari kerja ditunjukkan pada Gambar 2 sebagai berikut:

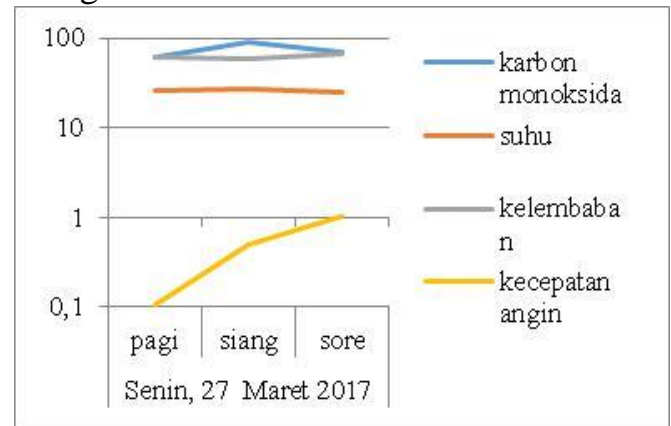

Gambar 2. Pola Distribusi Karbon Monoksida dan Parameter Meteorologis Berdasarkan Perubahan Waktu Pada Saat Hari Kerja

Dari kedua data hasil pengamatan konsentrasi CO dan parameter meteorologi di terminal Tawang Alun didapatkan pola kontur grafik yang tidak linier terhadap perubahan waktu. Terlihat bahwa konsentrasi $\mathrm{CO}$ mengalami peningkatan saat siang hari kemudian berangsur turun pada sore sampai sampai malam hari. Hal serupa juga terjadi pada nilai temperatur (suhu udara) di Terminal Tawang Alun. Namun tidak terjadi pada nilai kelembaban yang mengalami penurununan kadar uap air saat siang hari kemudian berangsur naik saat sore hingga menjelang malam hari.
Menurut hasil analisa data Rasyidi et al. (2015) menunjukkan bahwa tidak berkorelasinya antara kelembaban relatif dengan lapisan inversi, antara lapisan inversi dengan gas pencemar, serta kelembaban relatif dengan gas pencemar. Tidak berkorelasinya ini kemungkinan disebabkan oleh sinar dan panas matahari. Menurut penelitian Candrasari dan

Mukono (2013) Suhu berpengaruh terhadap terjadinya keluhan kesehatan berupa iritasi kulit, artinya semakin tinggi suhu udara maka mempunyai risiko 0,634 kali lebih besar untuk dapat terjadinya iritasi kulit. Sedangkan nilai kecepatan angin menunjukkan perubahan yang tidak terlalu signifikan terhadap perubahan waktu namun dapat memberikan hubungan yang linier, yakni semakin besar hingga waktu sore sampai menjelang malam hari. Pada penelitian Pradana dan Heriyanto (2011) angin mempengaruhi nilai kelembaban udara. Pada saat arus mudik dan balik kelembaban udara memiliki nilai yang cukup tinggi, hal ini dikarenakan keadaan cuaca di lokasi pengamatan dalam keadaan mendung dan angin berhembus cukup kencang.

Tabel 2. Nilai Hubungan Jumlah Kendaraan Terhadap Konsentrasi Gas karbon monoksida (CO) di Terminal Tawang Alun

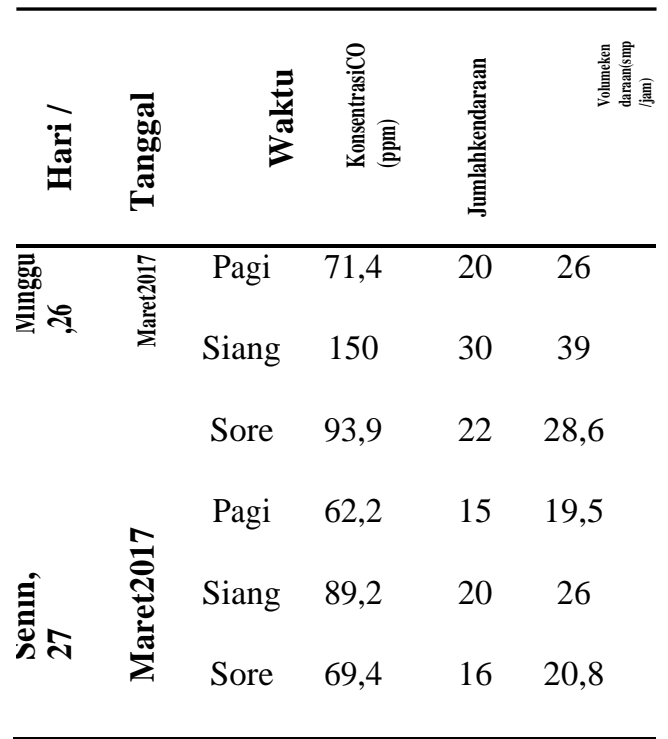


Berdasarkan Tabel 2, maka didapatkan bentuk grafik sebagai berikut:

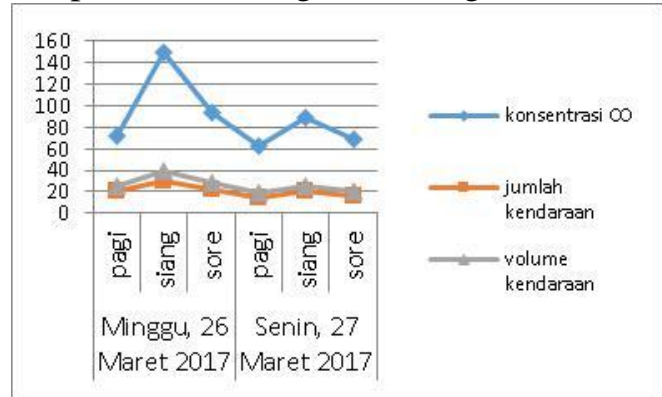

Gambar 3. Grafik Nilai Hubungan Jumlah Kendaraan Terhadap Konsentrasi Gas karbon monoksida (CO) di Terminal Tawang Alun

Dari Gambar 3 diketahui bahwa semakin padat volume kendaraan (bus) yang melintas, maka semakin besar pula kadar konsentrasi karbon monoksida di terminal Tawang Alun Kabupaten Jember.

Tabel 3. Nilai Konsentrasi Gas karbon monoksida (CO) di Terminal Tawang Alun dan di Persawahan

\begin{tabular}{|c|c|c|c|}
\hline & 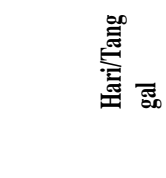 & $\frac{E}{\frac{E}{\pi}}$ & \\
\hline \multirow{5}{*}{ 恶焉离 } & Minggu, & Pagi & 71,36 \\
\hline & $\begin{array}{l}26 \text { Maret } \\
2017\end{array}$ & $\begin{array}{l}\text { Siang } \\
\text { Sore }\end{array}$ & $\begin{array}{c}150,20 \\
93,90\end{array}$ \\
\hline & Senin, 27 & Pagi & 62,20 \\
\hline & Maret & Siang & 89,20 \\
\hline & 2017 & Sore & 69,42 \\
\hline \multirow[t]{4}{*}{$\Phi=$} & $\begin{array}{c}\text { Minggu, } \\
9 \text { April }\end{array}$ & $\begin{array}{l}\text { Pagi } \\
\text { Siang }\end{array}$ & $\begin{array}{l}45,92 \\
48,41\end{array}$ \\
\hline & 2017 & $\begin{array}{l}\text { Sore } \\
\text { Pagi }\end{array}$ & $\begin{array}{l}24,07 \\
48,45\end{array}$ \\
\hline & April & Siang & 53,54 \\
\hline & 2017 & Sore & 28,42 \\
\hline
\end{tabular}

Dari Tabel 3, didapatkan grafik nilai konsentrasi gas karbon monoksida (CO) di terminal Tawang Alun dan di persawahan sebagai berikut:

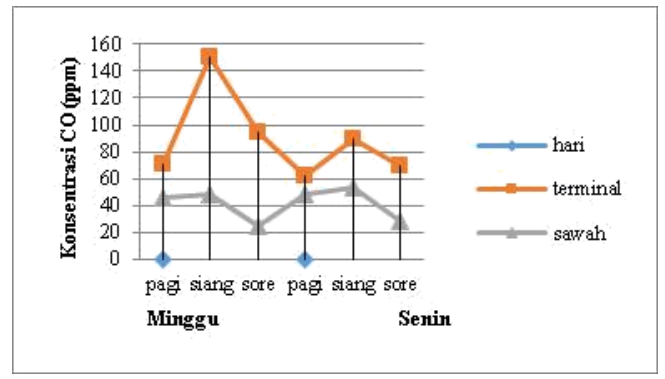

Gambar 4. Grafik Nilai Konsentrasi Gas karbon monoksida (CO) di Terminal Tawang Alun dan di Persawah

Dari Gambar 4 diketahui perubahan yang signifikan pada konsentrasi $\mathrm{CO}$ di terminal Tawang Alun dengan di daerah persawahan sebagai kontrol alamiah. Ratarata kadar $\mathrm{CO}$ di area persawahan turun sampai $41 \mathrm{ppm}$.

Dari hasil pengujian, didapatkan nilai signifikansi sebesar 0,015 yang berarti terdapat perbedaan yang signifikan di area persawahan dengan di terminal Tawang Alun. Hal ini terjadi karena didaerah persawahan merupakan daerah lapang yang memiliki laju angin lebih besar daripada didaerah perkotaan. Sehingga emisi gas polutan dapat lebih berkurang nilainya karena mudah tersebar ke berbagai arah. Besarnya emisi gas karbon monoksida yang terdeteksi di daerah persawahan berkisar 24-48 ppm pada hari libur dan 28$53 \mathrm{ppm}$ pada hari kerja. Sedangkan emisi gas karbon monoksida yang terdeteksi di terminal Tawang Alun berkisar 71-150 ppm pada hari libur dan 62-69 ppm pada hari kerja. Perbedaan pola ini terjadi karena aktifitas di daerah persawahan saat hari libur lebih sepi daripada saat hari kerja yakni hari senin yang merupakan waktu untuk memulai berbagai pekerjaan di area persawahan. Menurut Gorahe (2015) mengenai penelitian di tiga titik, yakni di jalan Piere Tendean, Jalan Ahmad Yani, dan jalan Sam Ratulangi memiliki kadar polusi udara (CO) maksimum pada hari Kamis dan Jumat. Hal ini berarti tingkat konsentrasi $\mathrm{CO}$ meningkat pada saat menjelang hari libur. 
Nilai baku mutu udara ambien untuk gas karbon monoksida di tetapkan selama satu jam pengukuran sebesar $30.000 \mu \mathrm{g} / \mathrm{Nm}^{3}$ atau sebesar $26,25 \mathrm{ppm}$. Bila dilihat dari hasil pengamatan rata-rata kadar gas karbon monoksida di terminal

Tawang Alun maupun didaerah persawahan keduanya termasuk dalam kondisi udara tercemar. Dampak negatif karbon monoksida sangat berpengaruh terhadap kesehatan pada mahluk hidup terutama manusia yang menghirupnya. Menurut hasil penelitian Kristanto et al. (2013) mengenai pemantauan kualitas udara area parkir didapatkan Konsentrasi CO melebihi baku mutu kualitas udara dalam ruang. Rata-rata konsentrasi $\mathrm{CO}$ mencapai $59 \mathrm{ppm}$. Menurut penelitian Rita et al. (2016) mengenai pemantauan kualitas udara di Banten, Jawa Tengah, dan Jawa Timur didapatkan kategori kualitas udara sedang. Menurut penelitian Sandra (2013) polusi udara yang terjadi diketahui mempunyai pengaruh yang signifikan dapat menimbulkan batuk kering dan sesak nafas disertai batuk serta dapat menurunkan fungsi paru Polantas. Sedangkan menurut penelitian Anggraeni (2009) diketahui bahwa $\mathrm{CO}$ bereaksi dengan $\mathrm{Fe}$ dari porfirin kemudian $\mathrm{CO}$ bersaing dengan oksigen dalam mengikat protein heme yaitu hemoglobin. Dengan

diikatnya $\mathrm{Hb}$ menjadi $\mathrm{COHb}$ mengakibatkan $\mathrm{Hb}$ menjadi inaktif sehingga darah berkurang kemampuan untuk mengangkut oksigen. Selain itu adanya $\mathrm{COHb}$ dalam darah akan menghambat disosiasi Oxi-Hb. Dengan demikian jaringan akan mengalami hipoksia.

\section{SIMPULAN DAN SARAN}

Berdasarkan hasil dan pembahasan diperoleh kesimpulan sebagai berikut: (1) pola distribusi konsentrasi $\mathrm{CO}$ dan parameter meteorologi di Terminal Tawang Alun didapatkan pola grafik yang tidak linier terhadap perubahan waktu.
Konsentrasi $\mathrm{CO}$ paling tinggi saat siang hari kemudian berangsur turun pada sore sampai menjelang malam hari dimana suhu semakin turun dan kelembaban udara meningkat. Berbeda dengan besarnya kecepatan angin yang menunjukkan pola distribusi linier seiring perubahan waktu. Hal ini terjadi pada saat hari libur maupun hari kerja; (2) terdapat hubungan antara volume kendaraan terhadap besarnya konsentrasi karbon monoksida di terminal Tawang Alun Kabupaten Jember. Semakin padat jumlah bus yang beroperasi di area Terminal, maka semakin tinggi pula tingkat cemaran gas karbon monoksida di udara terminal Tawang Alun Kabupaten Jember. Tingkat regresi antara pengaruh volume kendaraan terhadap besarnya konsentrasi karbon monoksida sebesar $82,3 \%$; (3) terjadi berbedaan yang signifikan pada konsentrasi CO di terminal Tawang Alun dengan di daerah persawahan. Adapun saran dari penelitian ini antara lain: (1) perlu adanya penelitian

lebih lanjut mengenai monitoring konsentrasi $\mathrm{CO}$ dan parameter meteorologi dengan variasi tempat penelitian sebagai perbandingan; (2) perlu adanya metode penelitian yang sesuai yakni minimal 10 meter di atas permukaan tanah; (3) perlu adanya sikap waspada dan peduli lingkungan kerja sebagai bentuk proteksi yang dilakukan pemerintah, misalnya melakukan pengadaan sistem monitoring yang lebih presisi setiap harinya serta membangun ruang terbuka hijau pada lahan kosong yang terdapat di sebelah selatan terminal yang masih digunakan sebagai tempat pembuangan sampah.

\section{DAFTAR PUSTAKA}

Anggraeni, S. 2009. Pengaruh Lama Paparan Asal Knalpot dengan Kadar CO 1800 ppm Terhadap Gambaran Histopatologi Jantung Pada Tikus Wistar. Laporan Akhir Penelitian Karya Ilmiah. Universitas Diponegoro. 
Aprilina, K., Badriah, I., U., dan Aldrian, E. 2016. Hubungan Antara Konsentrasi Karbon Monoksida (CO) dan Suhu Udara Terhadap Intervensi Anthropogenik (Studi Kasus Nyepi Tahun 2015 di Provinsi Bali). Jurnal Meteorologi dan Geofisika. Vol 17 (1): 53-60.

Arikunto, S. 2010. Prosedur Penelitian Suatu Pendekatan Praktik. Jakarta: Rineka Cipta

Candrasari, C.,R., Mukono, J., 2013. Hubungan Kualitas Udara Dalam Ruang Dengan Keluhan Penghuni Lembaga Pemasyarakatan Kelas IIA Kabupaten Sidoarjo. Jurnal Kesehatan Lingkungan. Vol. 7 (1): 21-25.

Ditjen Perhubungan Darat Provinsi Jawa Timur. 2013. Profil dan Kinerja Perhubungan Darat. Kabupaten Jember: Dinas Perhubungan.

Dinas Perhubungan Kabupaten Jember. 2016. Data Penumpang Terminal AKAP $A K D P$. Kabupaten Jember: Dinas Perhubungan.

Gorahe,I., M., dan Jansen, F. 2015. Pemodelan Hubungan Antara Arus Lalu Lintas dan Polusi Udara (CO) (Studi Kasus: Ruas Jalan Sam Ratulangi Depan Indo
Meubel, Ruas Jalan Ahmad Yani Depan Koni dan Ruas Jalan Piere Tendean Samping Patung Pahlawan). Jurnal Sipil Statik. Vol. 3 (7): 484-491

Haris, A., Ikhsan, M., dan Rita, R. 2012. Asap Rokok Sebagai Bahan Pencemar dalam Ruangan. Jurnal Cermin Dunia Kedokteran. Vol. 39 (1): 17-20.

Ismiyati, Marlita, D., dan Saidah, D. 2014. Pencemaran Udara Akibat Emisi Gas Buang Kendaraan Bermotor. Jurnal Manajemen Transportasi \& Logistik (JMTransLog). Vol. 1 (3): 241-247.

Kristanto, G., A., Sumabrata, J., dan Astuti, S., K. 2013. Analisis Kualitas Udara di Ruang Parkir Bawah Tanah dan Pengaruhnya Terhadap Pengguna. Jurnal Sains dan Teknologi Lingkungan. Vol 5 (2): 117-126.

Megalina, Y. 2015. Pengaruh Pencemaran Udara di Daerah Terminal Amplas Bagi Kehidupan Masyarakat. Jurnal Pengabdian Kepada Masyarakat. Vol. 21(79): 94-101 
Pradana, R., P., dan Heriyanto, E. 2011. Analisis Pemantauan Kualitas Udara Pada Saat Arus Mudik dan Balik Lebaran di Gerbang Tol Cikampek Tahun 2009. Jurnal Meteorologi dan Geofisika. Vol 12 (3): $261-269$.

Prasetyo, A. 2016. Kajian Pengaruh Pertumbuhan Ekonomi Terhadap Peningkatan Kemacetan Lalu Lintas di Perkotaan. Jurnal Penelitian Transportasi Darat. Vol. 18 (4): 231-242

Rasyidi, A., A., Hassan, H., dan Boedisantoso, R. 2015. Penentuan Korelasi Perubahan Kelembaban Relatif terhadap Ketinggian Inversi dan Kualitas Udara Ambien di Kota Surabaya. Jurnal Teknik ITS. Vol. 4 (1): 106-110.

Rita, D. D. Lestiani, E. H. Panjaitan, M. Santoso, dan H. Yulinawati. 2016. Kualitas Udara (PM10 dan PM2.5) Untuk Melengkapi Kajian Indeks Kualitas Lingkungan Hidup. Jurnal Ecolab. Vol 10 (1):1-7.
Sandra, C. 2013. Pengaruh Penurunan Kualitas Udara Terhadap Fungsi Paru dan Keluhan Pernafasan Pada Polisi Lalu Lintas Polwiltabes Surabaya. Jurnal Ikesma. Vol. 9

(1): 1-8.

Sarwono, B., K. 2010. Pemaknaan Kaum Perempuan Urban Terhadap Isu

Pemanasan Global dan Lingkungan di Media. Jurnal Ilmu Komunikasi. Vol. 8 (2): 178 - 190.

Sengkey, S.,L., Jansen, F., dan Wallah, S. 2011. Tingkat Pencemaran Udara CO Akibat Lalu Lintas Dengan Model Prediksi Polusi Udara Skala Mikro. Jurnal Ilmiah Media Engineering. Vol. 1(2): 119-120.

Soegeng, R. 1994. Ionosfir. Yogyakarta: Andi Offset..

Suryaningsih, S., Yuda, J., Hidayat, S., dan Chaerunnisa, I. 2017. Rancang Bangun Alat Ukur Kadar Gas CO Berbasis Nirkabel Rf Untuk Pemantauan Kondisi Pencemaran Udara. Jurnal Ilmu dan Inovasi Fisika. Vol. 1 (1): 45 - 50. 
Purnama, Monitoring Karbon Monoksida... 93 